\title{
A digitális megosztottság fogalmától az eInclusion politikájáig
}

Alig több mint egy évtizeddel ezelőtt még az információk, illetve az ezeket hordozó és továbbító info-kommunikációs eszközök puszta fizikai hozzáférési lehetőségeinek eltéréseiből, az ún. digitális megosztottságból adódó társadalmi-gazdasági különbségeket hangsúlyoztuk, nem a problémák megoldására, hanem magára a jelenségre koncentrálva. Mégis e fogalom segítségével sikerült felhívni a figyelmet arra, hogy az információs társadalmak is jelentős mértékben megosztottak, hiszen az IKT eszközök elterjedése jelentős mértékben felerősítette a már meglévő gazdasági, jövedelmi, foglalkoztatottsági stb. különbségeket. Az IKT eszközök készség-szintű, hétköznapi használata például a kommunikációban, a tanulásban, a munkavégzésben, a művelődésben, a szolgáltatások elérésében az életminőséget és az életesélyeket befolyásoló tényezővé vált. E minőségi változás következményeként mára Európában politikai normává vált a „befogadó információs társadalom” (e-Inclusion) programja, amely már nem a „szakadékra” reflektál, hanem az azt áthidalni képes eszközöket és lehetőségeket helyezi a középpontba.

Kulcsszavak: e-befogadás (e-Inclusion), társadalmi integráció, öregedő társadalom

\section{Szerzői információ:}

\section{Dombi Gábor}

1997-tól az Informatikai Érdekegyeztető Fórum (Inforum) fốtitkára, 1992 és 1997 között a Népszabadság munkatársa, a nol.hu (Népszabadság Online) alapítója. Mintegy kétezer cikk és tanulmány szerzôje. Az Internet Szolgáltatók Tanácsa mellett múködő Tanácsadó Testület titkára, a Miskolci Egyetem szociológia tanszékének vendégelőadója, a Civil Rádió „Infopoly: ember a hálózatban” címú músorának szerkesztốje. Az E-fesztivál zsúrijének elnöke, az Infonia Alapítvány kurátora, az Infopoly Alapítvány elnöke, valamint az e-befogadás és Információs Társadalom Tanács titkára. 2007-ben megkapta a Magyar Köztársaság Bronz Érdemkereszt, 2002-ben a Magyar Informatikáért díjat. Nebraska állam és City of Lincoln város (USA) díszpolgára.

E-mail: dombi.inforum@gmail.com

\section{Molnár Szilárd}

szociológus, jelenleg a Pécsi Tudományegyetem BTK kommunikációs doktori iskolájának hallgatója. 1998 óta dolgozik a BME-UNESCO Információs Társadalom- és Trendkutató Központban, 2006-tól mint kutatási igazgató. Fóbb kutatási területei: társadalmi tốke, civil társadalom, teleházak, esélyegyenlőség, e-közigazgatás. Több szakmai múhely vezetôje, az Inforum alelnöke, a Magyary Zoltán E-közigazgatástudományi Egyesület elnökségének tagja, a Magyar Kommunikációtudományi Társaság alapító tagja, a Telefalu közösségi honlap társszerkesztôje. 
Így hivatkozzon erre a cikkre:

Molnár Szilárd, Dombi Gábor. „A digitális megosztottság fogalmától az eInclusion politikájáig”. Információs Társadalom VIII, 2. szám (2008): 7-16.

- https://dx.doi.org/10.22503/inftars.VIII.2008.2.1 $\rightleftharpoons$

A folyóiratban közölt müvek

a Creative Commons Nevezd meg! - Ne add el! - Így add tovább! 4.0

Nemzetközi Licenc feltételeinek megfelelöen használhatók. 
Dombi Gábor - Molnár Szilárd

\section{A digitális megosztottság fogalmától az e-inclusion politikájáig}

\section{Gazdasági, társadalmi fenntarthatóság}

Az Európai Unió gazdasági és társadalmi versenyképességének megtartásához elengedhetetlen a teljes foglalkoztatottságra való törekvés, valamint a társadalmi kohézió és ennek részeként a szociális védelem és a társadalmi befogadás minél magasabb szinten történố megvalósulása. Az Unió intézményei hosszú évek óta szembesítik az európai közvéleményt az egyre kedvezôtlenebb demográfiai folyamatokkal, a foglalkoztatottság és a termelékenység terén jelentkezô gondokkal. Az elkövetkezendő évtizedekben az európai társadalmak túlnyomó többségének, így Magyarországnak is úgy kell fenntartania versenyképességét, hogy közben meg kell küzdenie a népesség csökkenéséból és a társadalom öregedéséból fakadó problémákkal is. A lemaradások számos mutató tekintetében hosszú évek óta vagy nem változnak, vagy rosszabbodnak, így a strukturális és kulturális változtatási kényszer a politika területén is sürgeti a befogadó információs társadalom megteremtését célzó reformokat.

A fejlett országok gazdasági és foglalkoztatási szerkezetének változása az ezredforduló után felgyorsult, s ehhez a megfelelő ütemben és irányban alkalmazkodnia kell a munkaerópiacnak is. Legfóbb tendenciaként a tudás- és szolgáltatásalapú gazdasági ágazatok dinamikus növekedése tapasztalható, ami teljesen új kihívások elé állítja a munkavállalókat. 2006-ban az EU-25 országokban már csak a foglalkoztatottak kevesebb mint egyötöde dolgozott a feldolgozóiparban, míg a szolgáltatások területén a foglalkoztatottak több mint kétharmada talált munkát. 2000 és 2004 között a tagállamokban több mint nyolcmillió új munkahely jött létre a szolgáltatószektorban, miközben az iparban és a mezôgazdaságban tovább csökkent a foglalkoztatottak száma.

2005-ben az EU-15 országokban a foglalkoztatottak valamivel több mint 40 százalékát alkalmazták az Eurostat által „tudásalapúnak” nevezett ágazatokban (a csúcs- és középtechnológiás feldolgozóipar és a tudásalapú szolgáltatások terén): a legnagyobb arányt Svédország (54\%), a legalacsonyabbat Portugália (26\%) mutatja. Az elmúlt tíz év során ezekben az ágazatokban a foglalkoztatás 24 százalékos növekedése messze meghaladta a gazdaság más ágazatainak fejlódési ütemét.

Az Európa elốtt álló legnagyobb kihívást ugyanakkor a népesség öregedése jelenti: amennyiben a következố néhány évben ezt nem sikerül hatékonyan kezelni, a kedvezôtlen demográfiai folyamatok maguk alá temetik a gazdasági és a szociális rendszerek fenntarthatóságát. Az Európai Bizottság becslése szerint a lakosság elöregedésének elsődleges hatása az lesz, hogy 2040-re az Unió lehetséges növekedési rátája a jelenlegi 2-2,25 százalékos arányról körülbelül 1,25 százalékra fog csökkenni, de a kedvezótlen tendencia természetesen már elóbb megmutatja hatását. A potenciális gazdasági növe- 
kedés már 2015-re megközelítóleg másfél százalékra csökkenhet, ha a munkaerôpiacban rejlő lehetôségeket csak a mai szinten sikerül kihasználni.

A versenyképesség elốmozdítása ma már egyértelmúen megköveteli a humántőkére, az új technológiák társadalmi alkalmazásának képességére irányuló befektetések növelését. A gazdasági szerkezet igen dinamikus változásainak eredményeként új foglalkoztatási elvárások jelentek meg. Ebben a kontextusban értékelődik fel az utóbbi években a befogadó információs társadalom eszméje és eszközvilága mint a foglalkoztatottság, a fokozódó mobilitás, az idôsebb generáció munkaerô-piaci integrációja és a megtartott életminőség nélkülözhetetlen biztosítéka.

A hagyományos európai gondolkodásmódban a társadalmi integráció, a befogadás kultúrája mindig is nagyon erôs szerepet játszott, s ennek megfelelôen az információs társadalom fejlesztésére irányuló programokban is egy igazságosabb, kevésbé töredezett társadalomkép jelenik meg. Már a 2002-ben elfogadott eEurope 2005 programban megfogalmazódott az „Információs társadalmat mindenkinek!” törekvés, de a digitális megosztottság szinte egyetlen területen sem csökkent az elvárt mértékben. Éppen ezért 2006-ban a 32 ország vezetôi által elfogadott rigai miniszteri deklaráció ${ }^{1}$ még határozottabb célokat túzött ki az e-inclusion tekintetében: 2010-re a leszakadással fenyegetett csoportok (idôsek, munkanélküliek, fogyatékkal élók) és a többségi társadalom között feszülő digitális megosztottságot a felére kell csökkenteni.

Az Európai Unió arra helyezi a hangsúlyt, hogy az idôsebb korosztály megtakarításainak gazdasági hasznosítása és az idôsek újjáélesztendő munkaerô-piaci aktivitása új lehetôségeket nyithat meg a foglalkoztathatóság növelése, az informatikai piac bővülése, valamint új szolgáltatások és eszközök megjelenése előtt, s mindezek révén elôsegíthetố a versenyképesség és a GDP növekedése, csökkenthetốk az egészségügyi kiadások, és fenntarthatóvá válik az idôsebb generációk életminôsége. Az Európai Uniónak egyértelmú az álláspontja: a társadalmi integrációt elôsegítő politika kifizetôdik, hiszen azzal, hogy több embert von be a munkaerôpiacra, és fenntarthatóbbá teszi az állami finanszírozási rendszereket, egyszersmind elősegíti a társadalmi kohéziót és a gazdasági növekedést is. A befogadó információs társadalom ügye és eszközrendszere Közép- és Kelet-Európában azonban - sajnálatos módon - nem elsôsorban ilyen szemlélettel, hanem fốként szociális, esélyegyenlôségi, életminőségi kérdésként és csak másodlagosan össztársadalmi, gazdasági szempontok alapján vetốdik fel. Ez a helyzet Magyarországon is, holott egyes számítások szerint egymillió új IKT- felhasználó bevonása a 45-75 éves korcsoportból körülbelül 160 milliárd forinttal ${ }^{2}$ bôvíthetné a hazai informatikai piacot egyetlen év leforgása alatt. Egy másik becslés szerint a digitális írástudás nem megfelelő szintje a hazai munkavállalók körében évente közel 300 milliárd forint ${ }^{3}$ kárt okoz a gazdaságnak azzal, hogy a dolgozók a kelleténél több idốt fordítanak a legegyszerúbb információfeldolgozási múveletek elvégzésére is. Sajnos az ilyen megközelítésú hatásbecslések szinte teljes mértékben hiányoznak hazánkban.

\footnotetext{
${ }^{1}$ http://ec.europa.eu/information_society/events/ict_riga_2006/doc/declaration_riga.pdf

${ }^{2}$ Lásd Dombi Gábor írását ugyanebben a folyóiratszámban.

${ }^{3}$ Lásd bővebben http://www.ecdl.hu/index.php?cim=opennews\&f=20080304_a_tudatlansag_ara.htm
} 


\section{Az e-befogadás európai programja}

Mindenképpen meglepó, hogy az Európai Unió (EU-27) átlagában igen magas még a legoptimistább becslések szerint is 40 százalék körüli - azoknak az aránya, akiknek semmilyen elốnyük nem származik a modern információs és kommunikációs eszközökból. 2007-ben jelentôs különbségek mutatkoztak az EU-27 országok lakosai, illetve háztartásai között. Uniós átlagban csak a háztartások 18 százalékában található széles sávú internet, és a lakosságnak alig több mint a fele használja rendszeresen az internetet. ${ }^{4}$ A legnagyobb mértékben egyes társadalmi csoportok, nevezetesen a 65 évnél idősebbek (14\%-os internethasználat), a gazdaságilag inaktív személyek (19\%-os internethasználat) és az alacsony képzettségúek (27\%-os internethasználat) maradnak le a lakossági átlagos értékektól. A közigazgatási szolgáltatásokat nyújtó honlapoknak mindössze 5 százaléka elégíti ki az e-elérhetôség nemzetközi követelményeit. Az elớrejelzések szerint az egyenlőtlenség mértékét 2010-ig sehol sem tudják a felére visszaszorítani, amennyiben az eddiginél nagyobb mértékú állami beavatkozás nem történik ezen a téren.

Az elektronikus társadalmi befogadás kérdéskörében 2005-re formálódott ki egységes európai politika. A Bizottság már ekkor javasolta, hogy 2008-tól elótérbe kell helyezni a társadalmi integráció, az esélyegyenlőség területét, az információs és kommunikációs technológiák kiterjedt használatára alapozva a teljes mértékben befogadó információs társadalom kiépítését. Az erôteljesen formálódó e-inclusion politika következő felvonása a már említett rigai miniszteri konferencia volt, ahol az európai politikai vezetók a digitális szakadék csökkentésének szükségessége mellett foglaltak állást. A 2010-ig elérendó lisszaboni célkitúzések az esélyegyenlőség dimenziójában így további célokkal egészültek ki. Az elsố és legfontosabb célkitúzés szerint meg kell felezni azt a szakadékot, amely a leszakadással fenyegetett csoportok (idốsek, munkanélküliek, fogyatékkal élók) és a többségi társadalom között tátong.

Az egyre határozottabb $e$-inclusion politika - melynek fontos állomása 2008, hiszen a befogadó információs társadalom (az e-befogadás) éve lett az Európai Unióban - arra hívja fel a figyelmet, hogy meg kell akadályozni az IKT-eszközök használata által felerôsödött társadalmi-gazdasági különbségek növekedését, mivel bármennyire is elutasító vagy közömbös magatartást tanúsítunk a modern infokommunikációs eszközökkel szemben, ezek mégis mindenkire egyforma hatással vannak.

Az e-inclusion politika azt mondja, hogy a befogadó információs társadalom aktív eszközei - például széles sávú infrastruktúra, e-közszolgáltatások, akadálymentes webkikötók, digitális írástudás - segítségével növelhető az információs társadalom integrációs ereje, javítható az esélyegyenlőség, a gazdasági aktivitás, a foglalkoztathatóság. Mivel az előzőekben bemutatott gazdasági és társadalmi gondok - még ha eltérő mértékben is - igen hasonlók az egyes országokban, az e-befogadás programja mára összeurópai érdekké vált.

A digitális megosztottság leküzdésével kapcsolatos törekvések fontos tapasztalata, hogy ez hosszan tartó, talán „végtelen” folyamat, amely komplex társadalompolitikai

${ }^{4}$ Az adatok az Eurostat oldaláról származnak. Lásd bóvebben http://epp.eurostat.ec.europa.eu/portal/ page?_pageid=1090,30070682,1090_33076576\&_dad=portal\&_schema=PORTAL 
beavatkozássorozatot igényel. Szükségszerú, hogy az állam proaktív módon, folyamatos politikai intervenciók útján kísérelje meg koordinálni az ezen a területen bekövetkezô fejleményeket.

A hálózati polgárok mindennapi, készségszintú IKT-eszközhasználatából, gyakorlatából látjuk, hogy mindez milyen elốnyökkel is járhat a munkavállalásban, a tanulásban, a szabadidő eltöltésében és a hétköznapi ügyek intézésében. Éppen ezért - paradox módon - az IKT-eszközök egyenlootlen elterjedése következtében kialakuló, illetve felerôsödő társadalmi megosztottságot ugyanezen eszközök segítségével próbálják csökkenteni. Napjainkban már úgy gondoljuk, hogy az IKT-eszközök alkalmasak arra, hogy segítségükkel javítsuk a leszakadó társadalmi rétegek, csoportok esélyeit, életminốségét. Az ezt kifejezố $e$-inclusion fogalma mögötti koncepció már nem elsôsorban az újfajta egyenlốtlenségek bemutatására koncentrál, hanem sokkal inkább az okok feltárását és a megosztottság áthidalását eloosegítố „nyertes-nyertes” megoldások kidolgozását tűzi ki célul. Természetesen nem számíthatunk arra, hogy az IKT-eszközök egy csapásra megoldják a szegénység, a diszkrimináció problémáit, és megszüntetik a társadalmi struktúrából eredő egyenlőtlenségeket. Arról van szó, hogy az IKT-eszközök elérése és tényleges használata, valamint az online tartalom- és egyéb (például közigazgatási) szolgáltatások igénybevétele csökkentheti a társadalmi kirekesztődést, és esélyegyenlőséget teremthet az információs társadalomban való részvétel tekintetében. A társadalomkutatók szerint a kevésbé széttöredezett, szolidáris közösségek sokkal sikeresebben tudnak alkalmazkodni a változó gazdasági-társadalmi körülményekhez, az új kihívásokhoz.

Összefoglalva: az e-befogadás európai uniós programja a társadalmi befogadás szociális céljait, a képzettség növelésének és a készségek elterjesztésének kulturális dimenzióját, valamint az informatika gazdaságerốsítố potenciáljának a munkaerôpiacra gyakorolt hatásait egybefoglaló mátrix politikai vetületeként jött létre.

\section{Az e-inclusion fogalma}

A digitális megosztottság vizsgálata tehát egyre újabb szempontokat nyújtott a társadalompolitikai szereplók számára, ugyanis ez a megközelítési mód nemcsak arra világít rá, hogy ki miért használja az IKT-eszközöket, hanem arra is, hogy ki miért nem tud vagy nem akar élni az új lehetőségekkel. Ez a szemléleti váltás vezetett el oda, hogy az IKT-eszközöket ma már nemcsak újabb társadalmi egyenlő́tlenségeket okozó eszközöknek, hanem egyúttal éppen az egyenlőtlenségek csökkentésére és a hátrányos helyzetû́ lakossági csoportok esélyteremtésére is felhasználható eróforrásnak is tekintjük. Ennek a minốségi változásnak a következményeként a „digitális megosztottság” leíró fogalmát felváltotta a normatív jellegú „,befogadó információs társadalom” (e-inclusion) kifejezés, amely már nem a „szakadékra” reflektál, hanem az azt áthidalni képes aktív eszközöket, lehetôségeket és törekvéseket hangsúlyozza.

Az e-inclusion kifejezés mögött meghúzódó koncepció tehát már nem elsốsorban az újfajta egyenlő́tlenségek (a szakadék) bemutatására, hanem sokkal inkább az okok feltárására és a megosztottság megszüntetését vagy legalábbis csökkentését elősegítô megoldások (hidak) megteremtésére koncentrál. Ennek következtében a „digitális 
megosztottság" statikus kifejezésének helyét egyre inkább az e-inclusion fogalma, illetve az ezzel a kifejezéssel jelölt dinamikus társadalmi-politikai program veszi át, ami az IKT-eszközökhöz való hozzáférés megteremtése és az ehhez kapcsolódó készségek kialakítása révén segíti elố a társadalmi integrációt, mindenki számára biztosítva a jóllét, a jó életminôség jogát.

\section{A befogadó információs társadalom esélye Magyarországon}

Sajnos Magyarországon még erôteljesebben érvényesülnek a már említett kedvezốtlen foglalkoztatottsági mutatók, az öregedô társadalom tendenciái. Az új gazdasági és foglalkoztatási szerkezetnek való megfelelés igénye, elfogadó attitûdje különös hangsúllyal vetódik fel a magyar lakosság körében. A foglalkoztatási szintre vonatkozóan az európai foglalkoztatási stratégiában meghatározott célkitúzésekhez képest (2005-ig 67\%-os, 2010-ig 70\%-os foglalkoztatási szint elérése) Magyarország elmaradása igen jelentős. Jelenleg Magyarországon majdnem négymillió 50 évnél idôsebb ember él, és a lakosság száma 2030-ra irányadó becslések szerint 9 millió före fog csökkenni. Mindeközben az idôsebb korosztálynak meglepóen alacsony a foglalkoztatási aránya: Magyarország esetében az 55-64 év közöttiek, tehát a még nem nyugdíjasok körében csak minden harmadik állampolgár dolgozik.

Az 55-64 év közötti korosztály foglalkoztatási rátája (\%)

\begin{tabular}{|l|c|c|c|c|c|c|c|c|}
\hline & $\mathbf{1 9 9 5}$ & $\mathbf{2 0 0 0}$ & $\mathbf{2 0 0 1}$ & $\mathbf{2 0 0 2}$ & $\mathbf{2 0 0 3}$ & $\mathbf{2 0 0 4}$ & $\mathbf{2 0 0 5}$ & $\mathbf{2 0 0 6}$ \\
\hline EU 27 & & 36,9 & 37,7 & 38,5 & 40,0 & 40,7 & 42,4 & 43,5 \\
\hline Magyarország & & 22,2 & 23,5 & 25,6 & 28,9 & 31,1 & 33,0 & 33,6 \\
\hline USA & 55,1 & 57,8 & 58,6 & 59,5 & 59,9 & 59,9 & 60,8 & 61,8 \\
\hline Japán & 63,7 & 62,8 & 62,0 & 61,6 & 62,1 & 63,0 & 63,9 & 64,7 \\
\hline
\end{tabular}

(Forrás: Eurostat, 2008)

Szinte teljes mértékben hiányzik a részmunkaidôs foglalkoztatás, ami különösen az idősebbek körében igen hatékony lehet. A hazai munkavállalók mindössze 4 százaléka dolgozik ilyen formában, szemben az Unió 18 százalékos arányával. Semmivel sem mutat jobb képet a valamilyen oktatási vagy képzési programban részt vevók aránya sem: 2007-ben Magyarországon az 55-64 év közöttieknek csak 4 százaléka vett részt valamilyen képzésben, szemben az Unió 30 százalékos átlagos részarányával ugyanebben a korosztályban.

A munkaerô-piaci feszültségeket az európai országok többsége - így Magyarország is - elsősorban a kínálat csökkentésével próbálta kezelni, ez azonban felerôsítette az öregedő társadalmakban egyébként is gyarapodó inaktív kör dinamikus növekedését, míg az Egyesült Államokban a szolgáltatási szektor növekedése bővíteni tudta a foglalkoztatást. A szükségszerú strukturális változások irányát Magyarországon eddig nem sikerült sem általános társadalompolitikai, sem foglalkoztatás- vagy éppen oktatáspolitikai beavatkozási csomagokkal befolyásolni: változatlanul a strukturális munkanélküliség terhe nehezedik az országra. 
Magyarországnak sincs más választása, mint a foglalkoztatottsági ráták növelése. A foglalkoztatás magas szintje nélkülözhetetlen a nagyobb társadalmi kohézió megteremtéséhez, a szegénység csökkentéséhez. A szociális/jóléti rendszerek társadalmi és pénzügyi fenntarthatóságát csakis több aktív munkavállaló foglalkoztatása biztosíthatja. Éppen ezért a lisszaboni célok továbbra is a 70 százalékos foglalkoztatási ráta elérését irányozzák elő 2010-re a teljes lakosság viszonylatában, ami a nók körében 60 százalékos, az idôs munkavállalók esetében pedig 50 százalékos foglalkoztatási szintet tételez fel.

Magyarország demográfiai trendje egyre romló gazdasági-szociális helyzetet von magával, ugyanis az egyre nagyobb számú inaktív népesség mögött csupán fogyatkozó lélekszámú „járulékfizetô” generáció sorakozik fel, azaz a jelenlegi szociális/jóléti rendszer nem tartható fenn.

Ennek ellenére Magyarországnak nincs olyan átfogó „aktív öregedési” stratégiája, amely az idốsebb generáció munkaerố-piaci - tágabb értelemben szocioökonómiai - integrációját segítené elố. Ugyanakkor nincs más lehetốség, mint növelni az idôs munkavállalók jelenlétét a munkaerốpiacon, amit viszont csak úgy lehet elérni, ha az idősebb korosztályok aktívak maradnak, és megvannak azok a képesítéseik és készségeik, amelyek birtokában meg tudnak felelni a tudástársadalom kihívásainak. Magyarország egyelốre nem szentel kellố figyelmet annak a nézốpontnak, illetve látásmódnak a kialakítására, ami az öregedố társadalom és a befogadó információs társadalom aktív eszközeit és lehetôségeit a gazdasági-társadalmi versenyképesség, a foglalkoztathatóság, az iskolázottság, a képességek növelése, valamint az ezeknek köszönhetốen elérhetố piaci lehetőségek, a produktivitás és a növekvoó belső fogyasztás felól közelítené meg.

Az idősödés nem állapot, hanem tanulási folyamat: erre (is) fel kell készíteni a társadalom tagjait. Az e-inclusion program célcsoportjainak az egyik szegmense még csak idôsödik, és nem gondol a jövőre. A TNS-NRC kutatócégek közös felmérési adatai ${ }^{5}$ szerint 2007. év elsó félévében a 35-49 év közötti lakosságnak csupán 38 százaléka volt internethasználó, míg e korosztály 62 százaléka egyáltalán nem használta az internetet. Ez az adat azért riasztó, mert azt jelzi, hogy az aktív korú lakosságban egy igen jelentôs lélekszámú csoport nem ismerte fel a folyamatos fejlődés, a tanulás kényszerítố életszükséglet mivoltát, és tagjait erôsen fenyegeti az a veszély, hogy fejlôdésképtelenségük miatt munkaerejük leértékelődik. Kimondhatjuk, hogy a 35-49 év közötti korosztály 62 százaléka - azáltal, hogy nincs tisztában az internetben rejlő előnyökkel, nem ismeri a modern eszközök használatát - jelentékenyen csökkenti nemcsak a saját esélyeit, hanem az ország versenyképességét is. Ráadásul éppen ez a korcsoport viseli a vállán az ország és a társadalom terheit, támogatja szüleit, gyereket nevel, dolgozik és adózik, miközben autó- és lakáshiteleit törleszti. Mostanra olyan helyzet állt eló, hogy bár fejlett technológiát alkalmazó beruházók érkez(né)nek Magyarországra, munkaeróigényük kielégítése a hazai kínálat alapján (a korszerú ismeretek hiányában) nem lehetséges. A digitális írástudás fejlesztése ebben a kontextusban versenyképességi kényszer.

Az Európai Unió cselekvési terveinek súlypontjában az idôsödés áll, ám ebben a tekintetben feszültség érhetố tetten a Nyugat-Európára jellemzố logika és a magyarországi (kelet-európai) gondolkodásmód között. Az Európai Unió arra épít, hogy egyéb források mellett az idôsebb generációk munkaereje és megtakarításai is mozgósíthatók

\footnotetext{
${ }^{5}$ http://www.nrc.hu/hirek? page $=$ details\&news_id $=427$
} 
annak érdekében, hogy az informatika számára új piac nyíljék meg, és erre a piacra új szolgáltatások és eszközök kerüljenek, hogy a versenyképesség és a GDP ily módon történő növelése révén csökkenthetók legyenek az egészségügyi kiadások az idősebb generációk életminőségének fenntartása mellett.

Magyarországon azonban 45-50 éves életkor felett bekövetkezik a létbizonytalanság korszaka: aki ebben a korosztályban elveszíti a munkáját, nehezen vagy sehogy sem talál újat. A családi, kisközösségi, települési összetartó és megtartó kötelékek a társadalom jelentôs részében meglehetôsen gyengék. A 40 év feletti korosztályok tagjainak nem adatott meg, hogy felhalmozzanak idősebb napjaikra (tehát szegényebb generációkról van szó), s bár az embereknek vannak bizonyos megtakarításaik, azok nem túlságosan nagymértékúek. Az informatika azt kínálja számukra, hogy online módon kevesebb idő́, pénz- és energiaráfordítással juthatnak információkhoz, megmaradhatnak már kialakult szociális hálózataikban, vagy újakhoz csatlakozhatnak, és bekapcsolódhatnak olyan oktatási formákba, amelyek révén továbbképezhetik magukat, hogy munkaeró-piaci versenyképességüket megốrizzék. A fokozottan hátrányos helyzetú csoportok esetében mindez sokszorosan felértékelődik, hiszen számukra - akár a fizikai hátránnyal, fogyatékkal élókre, akár az etnikai kisebbség tagjaira gondolunk - a többségi társadalommal való kapcsolattartást elóítéletek is terhelik. Az e-inclusion politika tárgya tehát az Elba folyótól nyugatra elsốsorban idôsödési, gazdasági, IKT-fejlesztési és végsố soron versenyképességi kérdés, Kelet- és Közép-Európa azonban még nem érte el ezt a társadalmi-gazdasági fejlettségi szintet, így ennek köszönhetốen itt az $\ell$-inclusion politika elsősorban szociális és esélyegyenlőségi célokat szolgál, nem pedig egy komplex informatikai, gazdasági, államigazgatási programcsomag hozadékaként jelenik meg.

Magyarország információs társadalmából az idôsebb generáció szinte teljes mértékben ki van zárva, aminek következtében sajátosan kettốs társadalomkép rajzolódott ki az utóbbi években. Egyrészt megtalálható az a réteg, amelyik szinte minden mutatójában az európai átlagértékeknek megfelelóen teljesít mind az infrastrukturális ellátottság, mind a használat, mind az attitúdök tekintetében. Ebben a körben rendre észlelhetó a technológiaváltás (például a széles sávra való áttérés, a mobilitást elősegító technológiák használata), amely magával vonja a hozzáadott értéket magukban foglaló online tartalom- és egyéb szolgáltatások kiterjedtebb használatát. Összességében elmondható erról a rétegról az is, hogy a nagyobb állami programokat és akciókat - amilyen például „Sulinet Expressz”, a széles sávú infrastruktúra elérhetôvé tétele, a hozzáférési árak letörése, az online közszolgáltatások beindítása volt a közelmúltban - elsôsorban ók használták ki, ezeknek a kezdeményezéseknek elsôsorban ók a nyertesei.

Másrészt azonban igen jellemző hazánkra a másik véglethez tartozó, az információs társadalmat elutasító és a kihívásokra közömbösséggel reagáló állampolgárok magas aránya is. Ezek sok tekintetben nagyon sajátos réteget alkotnak, amelyre leginkább a digitális kultúra, az új lehetốségek iránti közömbös beállítódás, a társadalmi, szociális értelemben vett elszigetelődés jellemzó, és ez sajnos megnehezíti az információs társadalom értékeinek és lehetốségeinek tudatosítását ebben a körben. Az idetartozókat szinte alig érintették meg az eddigi nagyobb állami programok, így az információs társadalom fejlesztésével kapcsolatban elsősorban ennek az igen széles rétegnek köszönhetôen alakul ki hazánkról az a kép, hogy az alapvetố infrastrukturális mutatókkal (a számítógép- és internethasználat a háztartásokban, széles sávú elérés) is gondjaink 
vannak, az új viszonyítási pontokról, például a digitális írástudás alacsony szintjéról nem is beszélve. A hazai fejlesztési programok, köztük az e-befogadás megvalósítását nagymértékben nehezíti, hogy a legszélesebb társadalmi spektrumban ilyen vegyes képet találunk. Miközben még mindig évekkel ezeloótti problémák kezelését, például a háztartások elégtelen infrastruktúrájának fejlesztését, a hozzáférés rossz mutatóinak javítását is meg kell oldani, a digitális írástudás, a hozzáadott értéket tartalmazó online szolgáltatások igénybevétele terén újabb kihívások jelentkeznek.

Az információs társadalom, a digitális kultúra elfogadására vonatkozó hazai adatokat áttekintve ugyanez a markáns „kettốsség rajzolódik ki elốttünk. Miközben hazánkban a digitális szakadék még a hozzáférés szintjén is jelentôs - csak a háztartások felében található egyáltalán személyi számítógép -, addig az IKT-eszközöket már használók körében is tapasztalható az életminőség tekintetében fellépó megosztottság.

A digitális megosztottság különböző szintjei Magyarországon ${ }^{6}$

\begin{tabular}{|l|l|c|}
\hline Hozzáférési megosztottság & PC a háztartásokban & $49 \%$ \\
\cline { 2 - 3 } & Otthoni széles sáv & $29 \%$ \\
\hline \multirow{3}{*}{ Használati megosztottság } & Felnốt lakosság PC-használata & $50 \%$ \\
\hline & Munkahelyi PC-használat & $30 \%$ \\
\hline & Felnótt lakosság internethasználata & $40 \%$ \\
\hline \multirow{3}{*}{ Minőségi megosztottság } & Az e-közigazgatási szolgáltatások használata & $25 \%$ \\
\hline & Online bankolás & $18 \%$ \\
\hline & Részvétel távoktatásban & $13 \%$ \\
\hline
\end{tabular}

Az adatokból kiolvasható, hogy a fizikai hozzáférés és a használat tekintetében egyaránt jelentốs mértékú a megosztottság, és a digitális „spektrum” két végén elhelyezkedố csoportok - a hozzáféréssel még nem rendelkezók, illetve a minốségi szolgáltatásokat már rutinszerúen használók - egyre távolabbra kerülnek egymástól. A megosztottság csökkentésére természetesen voltak már jó kezdeményezések és fejlesztési programok - mindhárom megosztottsági típus esetében - hazánkban is, azonban ezeknek a megvalósítása többnyire nem volt elég sikeres. Nem sikerült hasonló intenzitással végrehajtani az infrastruktúra, az oktatás és a tartalomszolgáltatás terén egyaránt szükségessé váló feladatokat, és ezért most sok helyen elvarratlan szálakkal találkozunk: többfrontos harcot kell vívni, egyszerre lépve elóre valamennyi területen.

A jelenlegi romló gazdasági helyzetben, a jövedelmek reálértékének csökkenése idején különösen felértékelôdik az e-inclusion politika mint az életminôség megtartásának eszköze. Az alkalmazásban állók jelentôs részének a munkáltatója különféle bónuszokat, addicionális kedvezményeket és kompenzációs juttatásokat (munkaruhát, utazási és étkezési hozzájárulást, célprémiumokat stb.) nyújt a dolgozóknak, de ezek a jövedelemkiegészítési formák a munkaerốpiac hátrányosabb szektoraiban foglalkozta-

${ }^{6}$ Lásd bôvebben Molnár Szilárd: A digitális megosztottság értelmezési kerete. Információs Társadalom, 2002, 4. szám, 82-101, letölthetơ: http://einclusion.hu/2008-02-03/digitalis-megosztottsag/

${ }^{7}$ Az adatok forrása: World Internet Project 2007 adatainak gyorsjelentése. 
tottak, az inaktív rétegek, a hátrányos helyzetúek és a tartósan betegek számára ritkán érhetốk el. Ezekben a rétegekben az online világba való belépés lehetôségének megteremtése (és megragadása), a hálózati csatlakozás, a tanulás, a saját számítógép és más digitális eszközök birtoklása, valamint a korszerú technológiák alkalmazásához szükséges készségek megszerzése kifejezetten emancipatív hatással jár, mert növeli az esélyeket, és alapot nyújt magabiztosabb fellépéshez számos területen. Az e-inclusion célcsoportjai számára nyújtandó kedvezmények - például oktatás, mentorálás, eszközök, közösségi terek - olyan kompenzációs szolgáltatások, amelyek hatalmas egyéni és társadalmi eredményt hoznak annak ellenére, hogy nem kerülnek olyan sokba, mint ha közvetlen anyagi támogatással igyekeznénk megelốzni vagy megállítani az életminőség romlását. Ezért állíthatjuk, hogy az e-inclusion politika Magyarországon túlmutat önmagán, és a társadalompolitika egyik alapvetố összetevôjeként egyszersmind életminôség-politikát is jelent.

Az e-befogadás politika tehát nemcsak kisebb-nagyobb csoportok segítésére szolgál, hanem azzal, hogy a célba vett rétegek számára közösségi teret, oktatást, személyre szabott támogatást (mentorálást), valamint társadalmi és virtuális hálózatokat is biztosít, valójában az egyének életminôségét javítja, ami pozitív politikai, társadalmi és gazdasági eredményekhez vezet. Azáltal, hogy belépnek az online világba, az új felhasználók új szolgáltatási igényeket gerjesztenek, és az új technikai eszközök fogyasztóivá válnak (még akkor is, ha kezdetben csekély vásárlóerốt képviselnek), továbbá növelik nemcsak az internetes penetrációt, hanem az informatikai, telekommunikációs, média- és reklámpiacokat is. Keresletet támasztanak az oktatás és továbbképzés területén, s ez alapja lehet újabb kompetenciák és készségek elektronikus úton történó elsajátításának. ${ }^{8}$ Mindez pedig elvezethet a munkaerốpiacon való megjelenésükhöz, ahol képesek lehetnek távmunkát is vállalni, és bekapcsolódhatnak különféle önkéntes és öntevékeny akciókba.

Az e-inclusion mint társadalompolitikai program végrehajtását azonban Magyarországon egyelőre többirányú útkeresés jellemzi. Az egyik irány az állami kezdeményezésú, központi iránymutatással koordinált, nagylélegzetú beavatkozások együttese, amelyben a minisztériumok mellett civil szervezetek és vállalkozások is részt vesznek. A második irányt a széttagolt intézményi programok jelentik, amelyek alárendelten jelennek meg más minisztériumi programok mellett, s ezekkel párhuzamosan, gyakorlatilag kapcsolódási pontok nélkül bukkannak fel a civil szervezeti és vállalati kezdeményezések. A harmadik irány közös cél felé fordítja az állam, a civil szervezetek és a vállalatok törekvéseit, amelyek támogatóként vagy társfinanszírozóként vesznek részt a feladatok megoldásában, és konszenzuson alapuló megállapodások keretében indítja be a közérdekú programokat - ez jelentené az erőforrások optimális harmonizációját. Sajnálatos módon jelen van továbbá egy negyedik irány is: az egyes tárcák és szervezetek gyakorlatilag önállóan végzik a maguk elé túzött feladatokat, és akcióikra csupán ráhúzzák az e-inclusion logóját, akár odaillik, akár nem.

${ }^{8}$ Ezért különösen fontos, hogy a mentorok és segítók, a „digitális népmúvelók” éppen abból a célcsoportból kerüljenek ki, amelyeknek a mozgósítása a cél. 


\section{Források}

A digitális jövó térképe. Jelentés a World Internet Project 2007. évi magyarországi kutatásainak eredményeiról. 2007, ITHAKA Kht.

Dombi Gábor - Kollányi Bence - Molnár Szilárd 2007. Társadalmi befogadást most! Az életminốség, digitális esélyegyenlöség és a társadalmi megújulás Magyarországa. e-inclusion éves jelentés.

e-befogadás Szakértới Munkacsoport 2008. Aze-befog@dás irányai és lehetóségei 2007 és 2013 között. Szociális és Munkaügyi Minisztérium-Szociálpolitikai és Munkaügyi Intézet.

Európai Bizottság 2007. Idôsödés jólétben az információs társadalomban. Az információs és kommunikációs technológiákra és az öregedésre vonatkozó cselekvési terv. Innen: http://einclusion.hu/2007-11-20/idosodes-joletben-az-informacios-tarsadalombani2010-kezdemenyezes-cselekvesi-terv/

Európai Bizottság 2006. Broadband gap policy. Innen: http://ec.europa.eu/information_society/eeurope/i2010/digital_divide/index_en.htm

Európai Bizottság 2007. Action plan offers support to older ICT users.

Európai Bizottság 2007. i2010 - Annual Information Society Report. SEC(2007), 395.

Európai Bizottság 2007. Measuring progress in e-inclusion. Riga Dashboard.

KSH 2006. A magyarországi háztartások infokommunikációs (IKT) eszközellátottsága és az egyéni használat jellemzóí.

Ministerial Debate on e-inclusion Policy - Event and Exhibition. Conference Summary. Lisbon, Portugal, 2-3 December 2007. 